\title{
TRICHOSPORON PULLULANS (LIDNER) DIDDENS \& LODDER ISOLATED FROM THE ORAL CAVITY OF AIDS PATIENT
}

\author{
Rejane Pereira Neves; Maria Auxiliadora de Queiroz Cavalcanti*; Guilherme Maranhão Chaves; \\ Oliane Maria Correia Magalhães
}

Departamento de Micologia, Centro de Ciências Biológicas, Universidade Federal de Pernambuco, Recife, PE, Brasil

Submitted: January 30, 2002; Returned to authors for corrections: June 18, 2002; Approved: September 24, 2002

\section{SHORT COMMUNICATION}

\begin{abstract}
Trichosporon has been reported as a remarkable emerging pathogen and usually occurs in imunodrepressed patients. An oropharyngeal secretion sample was collected from a patient with AIDS, at the Sector of Infectious and Parasitic Diseases, Osvaldo Cruz University Hospital, Pernambuco State, Brazil. No yeast cells or arthroconidia were observed in the direct exam, but a culture was positive for Trichosporon pullulans, which is being reported in an AIDS patient for the first time.
\end{abstract}

Key words: Trichosporon pullulans, AIDS.

The importance of the study of fungi as pathogenic agents from the oral cavity has been reported, indicating the mouth as an entrance of many mycosis etiological agents $(11,14,15)$.

Trichosporon is found in the indigenous mycobiota of the skin surface, mainly in the genito crural and perianal areas of homosexuals (17).

Hematogenic dissemination due to Trichosporon species is frequently observed in patients with low immunity, particularly in cases of neutropenia or leukemia $(6,10,16)$. Among the species connected to mycosis, T. pullulans is recognized as usually occurring in imunodepressed individuals $(2,6,8,9,12)$.

This study reports the isolation of $T$. pullulans from a clinical sample of an AIDS patient, hospitalized in the Sector of Infectious and Parasitic Diseases, University Hospital Osvaldo Cruz, Pernambuco State University, Recife, Pernambuco.

The patient is a 35-years-old male (C.J.V.), living as a mason in Paulista (Recife Metropolitan Region - Pernambuco State, Brazil), and presented lesions in the oral cavity and underside of the tongue. The sample of oropharyngeal secretion was collected with a sterilized swab that was placed into a tube containing $2 \mathrm{~mL}$ of sterile destilled water plus $50 \mathrm{mg}$ of
chloranphenicol/L. At the Medical Mycology Laboratory (Department of Mycology, Federal University of Pernambuco), the sample was processed for direct examination and isolation in culture. The time from collecting to processing the sample did not exceed two hours.

The direct examination was performed on the fresh sample (without clarification and staining) and for the isolation, it spreading was performed on the surface of Sabouraud agar with $0.5 \mathrm{mg}$ of yeast extract $/ \mathrm{L}$ and $50 \mathrm{mg}$ chloranphenicol/L was placed and incubated at room temperature $\left(28^{\circ} \mathrm{C} \pm 2^{\circ} \mathrm{C}\right)$ for 10 days. After the isolation, a suspension using sterile distilled water plus $50 \mathrm{mg}$ of chloranphenicol/L, was prepared and 0.2 $\mathrm{mL}$ were placed on the surface of Sabouraud agar into tube. For identification, the morphophysiological and biochemical tests such as auxanogram, zimogram, acid and urease production were performed according to Barnett et al. (1), Kreger Van-Rij (7) and Lodder (13). The identification was confirmed by the VITEK 120 test.

No like-fungi structure was observed in the direct examination. Macroscopically the colony was cream, smooth, firm texture with irregular edges. In Sabouraud broth sediment

\footnotetext{
* Corresponding author. Mailing address: Av. Boa Viagem, 3376/92, Boa Viagem, 51020-001, Recife, PE, Brasil. Fax: (+5581) 3271-8480.

E-mail: xiliamac@terra.com.br
} 
was observed, but not ring or pellicle. Microscopically ovoid yeast cells, true mycelium and arthrospores were observed. Glucose, galactose, sucrose, lactose, trehalose, cellobiose, melezitose, raffinose, xylose, maltose and ammonium sulfate were assimilated as carbon and nitrogen sources. There was no fermentation or acid production and it was urease positive.

According to Barnett et al. (1) T. pullulans has been found in wood pulp, soil, pipelines in a brewery, butter, frozen beef and human nail, but no report of this species from the clinical samples of AIDS patients was found. On the other hand, $T$. pullulan has also been isolated from bovine mastitis (3), pigeon droppings (4), nasal infection in cats (5), cancer patients using (8) or not catheters (9), and leukemic patient associated with lung infection (16).

Hence, it is the first time that T. pullulans has been reported as isolated from AIDS patient.

\section{ACKNOWLEDGMENT}

Authors thanks to CAPES for financial support (scholarships).

\section{REFERENCES}

1. Barnett, J.A.; Paine, R.W.; Yarrow, D. Yeasts: characteristics and identification. University Press, Cambridge, 1990, 1002p.

2. Borderon, J.C. Deep Candida and related yeast infections. Rev. Prat., 39: 1657-1662, 1989.

3. Costa, E.O.; Gandra, C.R.; Pires, M.F.; Coutinho, S.D.; Castilho, W.; Teixeira, C.M. Survey of bovine mycotic mastitis in dairy herds in the State of São Paulo, Brazil. Mycopathologia, 124: 13-17, 1993.

4. Gallo, M.G.; Cabeli, P.; Vidotto, V. Presence of pathogenic yeasts in feces of the semi-domesticated pigeon from the city of Turin. Parasitologia, 31: 207-212, 1989.
5. Greene, C.E.; Miller, D.M.; Blue, J.L. Trichosporon infection in a cat. J. Am. Vet. Med. Ass. Hung., 187: 946-948, 1985.

6. Hsu, C.F.; Wang, C.C.; Huang, C.S.; Cheng, S.N.; Chen Y.H.; Chu, M.L. Trichosporon beigelli causing oral mucosit and fungaemia: report of one case. Chung Hua Min Kuo Hsiao Erh Ko I Hsueh Hui Tsa Chih, 39: 191-194, 1998.

7. Kreger-van Rij, N.J.W. The yeast: a taxonomic study. Elsevier Sci Publication, Amsterdan, 1984, 1091p.

8. Kremery, V.J.; Mateika, F.; Kunova, A.; Spanik, S.; Giarfas, J.; Sycova, Z.; Trupl, J. Hematogenous trichosporonosis in cancer patients: report of 12 cases including 5 during prophylaxis with itraconazol. Support Care Cancer, 7: 39-43, 1999.

9. Kremery, V.J.; Oravicova, E.; Spanik, S.; Mrazova-Studena, M.; Trupl, J.; Kunova, A.; Stopkova-Grey, K.; Kukuckova, E.; Krupova, I.; Demitrovicova, A.; Kralovicova, K. Nosocomial breakthrough fungaemia during antifungal prophylaxis or empirical antifungal therapy in 41 cancer patients receiving antineoplastic chemotherapy: analysis of aetiology risk factors and outcome. J. Antimicrob Chemoter, 43: 373-380, 1998.

10. Kwon Chung, K.J.; Bennet, J.E. Medical Mycology. Lea \& Febiger, London, 1992, 615p.

11. Lacaz, C.S.; Porto, C.; Martins, J.E. C. Micologia Médica: fungos, actinomycetes e algas de interesse médico. Sarver-EDUSP, São Paulo, 1991, 695p.

12. Lascaux, A.S.; Bouscarat, F.; Descamps, V.; Casalino, E.; PicardiDahan, C.; Crickx, B.; Belaich, S. Cutaneous manifestations during disseminated trichosporonosis in an AIDS patients. Ann. Dermatol Venereol., 125: 111-113, 1998.

13. Lodder, J. The yeast: a taxonomic study. North Holland Publishing Company, Osford, 1970, 1385p.

14. Lucatorto, F.; Eversole, L.R. Deep mycosis and palatal perfuration with granulomatous pansinusitis in acquired immunodeficiency syndrome: Case reports. Quintess. Int., 24: 743-748, 1993.

15. Rippon, J.W. Medical Mycology: Hongos y Actinomicetos Patógenos. Copyright, México, 1990, 855p.

16. Shigehara, K.; Takahashi, K.; Tsunematsu, K.; Koba, H.; Katoh, S.; Asakawa, M.; Suzuki, A. A case of Trichosporon pullulans infection of the lung with adult T-cell leukemia. J. Med., 30: 135$137,1991$.

17. Zaitz, C.; Campell, I.; Marques, S.A.; Ruiz, L.R.B.; Souza, V.M. Compêndio de Micologia Médica. Medsi, Rio de Janeiro, 1998, $434 \mathrm{p}$. 